\begin{tabular}{llr} 
Jurnal Pendidikan Dasar Perkhasa & \\
http://jurnal.stkippersada.ac.id/jurnal/index.php/JPDP/ & P-ISSN 2461-078X \\
E-ISSN 2654-783X & & DoI : 10.31932/jpdp.v5i2.458 \\
\hline JPDP & JPD 5 (2) (2019) 104-115 &
\end{tabular}

\title{
MODEL INTEGRASI PENDIDIKAN KARAKTER DALAM PEMBELAJARAN ILMU PENGETAHUAN SOSIAL DI SEKOLAH DASAR
}

\author{
Hasnah Kanji*1 ${ }^{*}$ Nursalam², Muhammad Nawir ${ }^{3}$, Suardi $^{4}$ \\ ${ }^{1234}$ Universitas Muhammadiyah Makassar \\ Diterima: 4 Agustus 2019. Dipublikasi: 27 Oktober 2019.
}

\begin{abstract}
The main problem in this study is that students experience moral decadence that requires the integration of character education models in learning. The research method uses descriptive qualitative SD Inpres 34 Bungung Katammu, Bantaeng Regency. Determination of research informants by purposive sampling, namely the principal, teachers, students and parents. Data collection techniques using observation, depth-interview and documentation. Analysis techniques through data reduction, data display and conclusion drawing. Data wet technique is done through triangulation of sources, time and techniques. The results showed the integration model of character education consists of six levels of three levels, namely (a) at the individual level (i) moral knowing, (ii) moral feeling (iii) moral sinverbal. (b) at the individual-group level (i) moral action, (ii) moral habitus, (c) at the group level there is a moral culture that can integrate character values in social science subjects (IPS).
\end{abstract}

Keywords: Integration Model, Character Education, Learning, Social Sciences

Abstrak. Masalah utama dalam penelitian ini adalah kalangan pelajar mengalami dekadensi moral yang membutuhkan Model integrasi pendidikan karakter dalam pembelajaran. Metode penelitian menggunakan deskriptif kualitatif SD Inpres 34 Bungung Katammu Kabupaten Bantaeng. Penentuan informan penelitian secara purposive sampling, yaitu kepala sekolah, guru, siswa dan orang tua. Teknik pengumpulan data menggunakan observation, depth-Interview dan dokumentasi. Teknik Analisis melalui data reduction, data display dan conclusion drawing. Teknik kebasahan data dilakukan melalui triangulasi sumber, waktu dan teknik. Hasil penelitian menunjukkan model integrasi pendidikan karakter terdiri dari enam tingkatan dari tiga level yaitu (a) pada level individu (i) moral knowing, (ii) moral feeling (iii) moral sinverbal. (b) pada level individukelompok (i) moral action, (ii) moral habitus, (c) pada level kelompok ada moral culture yang dapat dintegrasikan nilai-nilai karakter pada mata pelajaran ilmu pengetahuan sosial (IPS).

Kata kunci: Model Integrasi, Pendidikan Karakter, Pembelajaran, Ilmu Pengetahuan Sosial

\section{Pendahuluan}

\begin{tabular}{lll}
\multicolumn{3}{c}{ Pendidikan adalah suatu usaha } \\
yang sadar dan & sistematis & dalam \\
mengembangkan & potensi & siswa. \\
Seharusnya & (das & sollen)
\end{tabular}
penyelenggaraan pendidikan di suatu

$\begin{array}{lcr}\text { negara menjadi tanggung jawab } \\ \text { negara untuk } & \text { melaksanakannya } \\ \text { dalam } & \text { rangka } & \text { mencerdaskan } \\ \text { kehidupan } & \text { bangsa. } & \text { Meskipun } \\ \text { demikian, rakyat juga memiliki hak } \\ \text { untuk ikut } & \text { serta dalam }\end{array}$

*surel korespondensi: hasnahkanji@gmail.com 
penyelenggaraan pendidikan. Praktik pendidikan di negara kita mengindikasikan bahwa pemerintah (negara) bersama-sama dengan rakyat cukup intens dalam penyelenggaraan pendidikan. Untuk kelancaran dan keberhasilan pendidikan, maka ditetapkan dalam Undang-undang (UU) No. 2 tahun 1989 tentang sistem pendidikan nasional yang kemudian diamandemen dengan keluarnya Undang-undang No. 20 tahun 2003 tentang sistem pendidikan nasional. Undang-undang inilah yang menjadi patokan bagi pemerintah dan masyarakat dalam penyelenggaraan pendidikan di Indonesia. Pasal 3 UU No. 20 tahun 2003 menegaskan bahwa pendidikan nasional berfungsi mengembangkan kemampuan dan membentuk watak serta peradaban bangsa yang bermanfaat dalam rangka mencerdaskan kehidupan bangsa, bertujuan untuk berkembangnya potensi murid agar menjadi manusia yang beriman dan bertagwa kepada Tuhan Yang Maha Esa, berakhlak mulia, sehat, berilmu, cakap, kreatif, mandiri, dan menjadi warga negara yang demokratis serta bertanggung jawab. Hal ini juga dipertegas oleh Peraturan Menteri, no 22 tahun 2006 tentang standar isi untuk satuan pendidikan dasar dan menengah. Untuk dapat meraih tujuan tersebut, pendidikan tidak cukup hanya menekankan pada proses dan penyediaan fasilitas yang mengarah pada penguasaan ilmu pengetahuan dan teknologi (hard skill) tetapi juga harus memfasilitasi tumbuh kembangnya karakterkarakter mulia seperti yang dirumuskan dalam tujuan pendidikan nasional di atas.

Namun kenyataannya (das sein) kalangan pelajar sekarang sedang mengalami dekadensi moral yang sangat memprihatinkan seperti perilaku menabrak etika, moral dan hukum dari yang ringan sampai yang berat masih kerap diperlihatkan oleh pelajar (Ahya, H. 2013), Kebiasaan mencontek pada saat ulangan atau ujian masih dilakukan (Akhwan, M. 2014), terlihat adanya yang menggejala di kalangan pelajar berbentuk kenakalan (Unayah, N., \& Sabarisman, M. 2015), Beberapa di antaranya adalah tawuran antar pelajar (Herawan, K. D., \& Sudarsana, I. K. 2017), meningkatnya kekerasan di kalangan pelajar (Pulungan, F. R. 
2012), semakin kaburnya moral baik dan buruk (Rohendi, E. 2018), menurunnya etos kerja (Arifin, I. 2017), semakin rendahnya rasa hormat terhadap orang tua dan guru (Novitasari, K. 2017), rendahnya rasa tanggung jawab individu dan warga negara (Suhono, S., \& Khumairo, A. 2018,), membudayanya ketidakjujuran (Rohendi, E. 2018,), adanya rasa saling curiga dan benci di antara sesama (Marlina, L., \& Nurman, G. 2017). Di beberapa kota besar tawuran pelajar menjadi tradisi dan membentuk pola yang tetap, sehingga di antara mereka membentuk musuh bebuyutan (Azmi, N. (2017), meminum minuman keras (mabukmabukan) (Tasik, F., \& Purwanto, A. 2018), pergaulan bebas (Sudarsana, I. K. 2018), ngisap lem (Simatupang, L. Y. 2018), gaya hidup hura-hura (hedonisme) (Tasik, F., \& Purwanto, A. 2018), penyalahgunaan obat-obat terlarang, (Soeroso, S. 2016), maraknya geng pelajar dan geng motor (Qibtiyah, M. 2017), kekerasan (bullying) (Amini, Y. S. J. 2008) dan bahkan tindakan kriminal seperti pemalakan, penganiayaan, bahkan pembunuhan (Rohayati, N. 2018), semua itu merupakan perbuatan tercela (amoral) yang itu jelas-jelas tidak mencerminkan adat dan budaya ketimuran kita yang diperparah oleh kendala guru dalam menginternalisasikan nilai karakter (Ahmad, T. A. 2014) dan kegagalan orag tua mendidik karakter anakanaknya (Daniel Goleman, 2000)

Semua perilaku negatif di kalangan pelajar tersebut, jelas menunjukkan kerapuhan karakter yang cukup parah dan salah satunya disebabkan oleh tidak optimalnya pengembangan karakter di lembaga pendidikan di samping karena kondisi lingkungan yang tidak mendukung. Untuk itu perlu dicari model terbaik untuk membangun dan mengembangkan karakter manusia dan bangsa Indonesia agar memiliki karakter yang baik, unggul dan mulia.

Upaya yang tepat untuk itu adalah melalui pendidikan sekolah (Ahya, H. 2013), karena pendidikan memiliki peran penting dan sentral dalam pengembangan potensi manusia, termasuk potensi mental. Melalui pendidikan diharapkan terjadi transformasi yang dapat menumbuhkembangkan karakter positif, serta mengubah watak dari yang tidak baik menjadi baik. Ki Hajar 
Dewantara dalam Usman, H., \& Raharjo, N. E. (2012) dengan tegas menyatakan bahwa pendidikan merupakan daya upaya untuk memajukan bertumbuhnya budi pekerti (kekuatan batin, karakter), pikiran (intellect), dan tubuh anak. Oleh karena itu pentingnya pendidikan karakter untuk memfasilitasi penguatan dan pengembangan nilai-nilai tertentu sehingga terwujud dalam prilaku anak, baik ketika proses sekolah maupun setelah proses sekolah atau setelah lulus dari sekolah (Kesuma, Triatna dan Permana, 2011: 9). Hal tersebut sangat perlu di tanamkan nilai-nilai karakter di lingkup sekolah khususnya dalam pembelajaran IPS (Akhwan, M. 2014). Pada dasarnya tujuan pembelajaran IPS adalah untuk mengembangkan potensi murid agar mampu beradaptasi dengan lingkungan sekitar, peka terhadap masalah yang terjadi di masyarakat dan mampu mengatasinya baik yang menimpa dirinya sendiri maupun yang menimpa masyarakat serta memiliki sikap mental positif terhadap perbaikan segala ketimpangan yang terjadi. Oleh karena itu, IPS sangat berperan terhadap interaksi sosial murid guna membentuk karakter dalam mengembangkan potensi yang bermanfaat untuk diri sendiri, masyarakat, bangsa dan negara. Maka demikian, IPS yang bersentuhan langsung terhadap kehidupan sosial murid, perlu dirancang sedemikian rupa untuk membentuk kepribadian yang berkarakter dalam menopang pengalaman-pengalaman sosial untuk membangun potensi diri. Selain itu, IPS juga dirancang untuk mencapai tujuan bersama dalam membentuk hubungan dengan sikap dan keterampilan sosial.

Dengan mengondisikan pembelajaran IPS yang kondusif, akan memungkinkan murid terlibat langsung dalam pembelajaran sebagai upaya mengembangkan pengetahuan, nilai, sikap, moral, dan keterampilan sosial. Murid mampu berperan serta dalam melakoni kehidupan masyarakat modern yang dinamis dalam rangka menyonsong era globalisasi sebagai generasi millenial. Pada akhirnya peran kritis yang diemban IPS untuk membentuk warga negara yang baik dapat terwujud. Sehingga pembelajaran IPS harus dirancang dan diselenggarakan secara sistematis guna mencapai tujuan 
tersebut. Oleh karena itu pentingnya model mengintegrasikan pendidikan karakter di sekolah khususnya pendidikan IPS di kelas tinggi. Masa kelas tinggi Sekolah Dasar (9 tahun sampai umur 12 tahun) termasuk dalam kelas IV, V,dan VI memiliki ciriciri yaitu (1) Sudah mulai mandiri; (2) Sudah ada rasa tanggung jawab pribadi; (3) penilaian terhadap dunia luar tidak hanya dipandang dari dirinya sendiri tetapi juga dilihat dari diri orang lain; (4) sudah menunjukkan sikap yang kritis dan rasional (Boojest, 2013). Sedangkan menurut Sebrinariz (2014) ciri-ciri pada masa siswa kelas tinggi (9/1012/13 tahun) yaitu (1) Minat terhadap kehidupan praktis sehari-hari yang konkret; (2) Sangat realistik, rasa ingin tahu dan ingin belajar; (3) Menjelang akhir masa ini telah ada minat kepada hal-hal atau pembelajaran khusus sebagai mulai menonjolnya bakat-bakat khusus; (4) Sampai usia 11 tahun anak membutuhkan guru atau orang dewasa lainnya untuk menyelesaikan tugas dan memenuhi keinginannya. Selepas usia ini pada umumnya anak menghadapi tugas-tugasnya dengan bebas dan berusaha untuk menyelesaikannya; (5) Pada masa ini anak memandang nilai (angka rapor) sebagai ukuran tepat mengenai prestasi sekolahnya, dan; (6) Gemar membentuk kelompok sebaya untuk bermain bersama. Dalam permainan itu mereka tidak terikat lagi dengan aturan permainan tradisional (yang sudah ada), mereka membuat peraturan sendiri. Sehingga pada tahap kelas tinggi sangat memungkinkan hasil pendidikan karakter sejak kelas rendah yang telah diajarkan atau diberikan oleh guru sudah mulai tampak hasilnya.

\section{Metode}

Penelitian ini adalah penelitian deskriptif kualitatif yaitu untuk memahami fenomena tentang apa yang dialami oleh subjek penelitian (Moleong, 2007), dengan pemahaman yang mendalam dari individu, kelompok atau situasi (Emzir, 2010: 20), untuk memaparkan, menggambarkan, dan memetakan fakta-fakta berdasarkan cara pandang atau kerangka berfikir tertentu (Bungin, 2007). Penelitian ini dilaksanakan di SD Inpres 34 Bungung Katammu, Kecamatan Bissappu, Kabupaten Bantaeng, berfokus pada 
penemuan model integrasi pendidikan karakter dalam pembelajaran ilmu pengetahuan social. Penentuan subjek dalam penelitian dilakukan dengan teknik purposive mencakup kepala sekolah, guru, siswa dan orang tua. Dalam penelitian ini yang menjadi instrument utama (key instrument) adalah peneliti sendiri berfungsi menetapkan fokus penelitian, memilih informan sebagai sumber data, melakukan pengumpulan data, menilai kualitas data, analisis data, menafsirkan data dan membuat kesimpulan atas temuannya (Sugiyono, 2011). Teknik pengumpulan data menggunakan pengamatan (observation), wawancara mendalam (depth-Interview) dan dokumentasi. Teknik Analisis Data penelitian ini dengan cara, reduksi data (data reduction), penyajian data (data display) dan verification (conclusion drawing) atau menarik kesimpulan berdasarkan hasil temuan. Teknik kebasahan data dilakukan melalui triangulasi sumber, triangulasi waktu dan triangulasi teknik.

\section{Hasil dan Pembahasan}

Model integrasi pendidikan karakter di sekolah dasar yang dikembangkan berdasarkan model pendidikan karakter moral knowing, moral feeling, moral action (Lickona, 2015, Ratna Megawangi 2004), yang yang menjadi lanjutan dan penghubung yaitu moral sinverbal, moral habitus dan moral culture sebagai model integrasi pendidikan karakter bangsa mulai level individu sampai pada kelompok. Berikut gambar model tersebut:

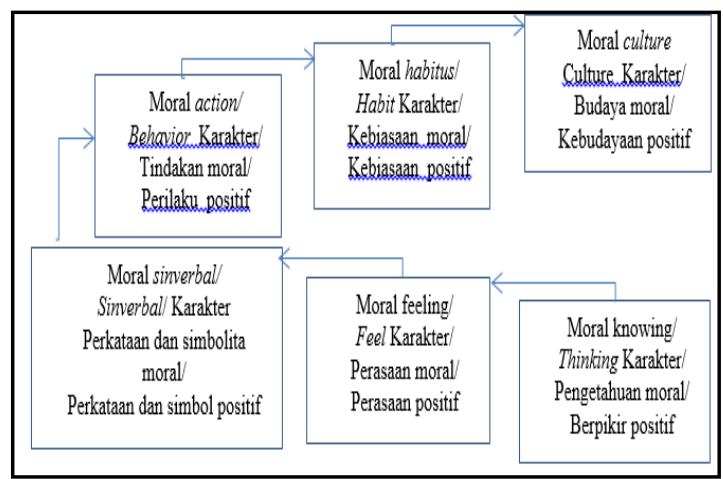

Gambar. 1. Tingkatan moral (knowing, feeling, sinverbal, action, habitus, dan culture pada level individu-kelompok). 
1. Moral knowing/ Thinking Karakter/ Pengetahuan moral/ Berpikir positif

Pada wilayah moral knowing guru mengajarkan berbagai pengetahuan tentang moral kepada siswa dalam pembelajaran ilmu pengetahuan sosial yaitu:

Mengajarkan kepada siswa kesadaran moral, merupakan penggunaan pemikiran untuk melihat segala situasi yang membutuhkan penilaian moral (baik atau buruk) kemudian setiap siswa memahami permasalahan berdasarkan situasi yang dialami. (b) Mengajarkan kepada siswa mengetahui sebuah nilai moral, yaitu bagaimana nilai dari moral yang dimiliki oleh siswa diaplikasikan dalam berbagai macam situasi yang dihadapai dalam kehidupan ini. (c) Mengajarkan kepada siswa penentuan presfektif yaitu siswa mengambil sudut pandang orang lain, melihat situasi sebagaiman orang lain melihat situasi, berpikir seperti orang lain berpikir, dan merasakan masalah yang ada berdasarkan sudut pandang orang lain. (d) Mengajarkan kepada siswa pemikiran moral, yaitu mengajarkan pemahaman tentang kepada siswa hakikat dari suatu moral dan mengapa harus bermoral. (e) Mengajarkan kepada siswa pengambilan keputusan, untuk memutuskan tindakan dalam melihat permasalah moral yang dihadapi. (f) Mengajarkan kepada siswa pengetahuan pribadi, yaitu mengetahui dan memahami diri sendiri, menilai dan mengevaluasi dirinya sendiri secara kritis. Pengetahuan moral yang diajarkan kepada siswa merupakan satu kesatuan pengetahuan moral yang memberikan konstribusi dalam pengembangan dalam sisi kognitif yang terkait dengan karakter siswa dalam pembelajaran ilmu pengetahuan sosial.

2. Moral feeling/ Feel Karakter/ Perasaan moral/ Perasaan positif Pada wilayah moral feeling guru mengajarkan berbagai perasaan tentang moral kepada siswa dalam pembelajaran ilmu pengetahuan sosial yaitu (a) Mengajarkan kepada siswa hati nurani untuk mengetahui apa yang benar dan melakukan apa yang dianggap benar. (b) Mengajarkan kepada siswa harga diri agar siswa tidak tergantung pada persetujuan orang lain dan tahan terhadap tekanan dari teman-teman atau siswa lain. (c) Mengajarkan kepada siswa empati, agar siswa dapat keluar dalam diri 
sendiri dan masuk dalam diri orang atau siswa lain. (d) Mengajarkan kepada siswa mencintai hal yang baik dan membenci yang buruk agar siswa selalu melakukan hal yang baik dan menghidari perbuatan yang buruk. (e) Mengajarkan kepada siswa kendali diri, agar siswa tidak memanjakan diri sendiri, dalam mengejar kesenangan dan keuntungan. (f) Mengajarkan kepada siswa kerendahan hati, agar siswa memiliki keterbukaan terhadap suatu kebenaran dan keinginan untuk memperbaiki kegagalan yang telah dialami. Perasaan tentang moral dapat mendorong siswa untuk selalu melakukan hal yang baik dan menghindari segala perbuatan yang buruk, sebagai perwujudan karakter.

3. Moral action/ Behavior Karakter/ Tindakan moral/ Perilaku positif Pada wilayah moral action guru mengajarkan berbagai pengetahuan dan perasaan tentang moral yang dimiliki siswa dalam pembelajaran ilmu pengetahuan sosial untuk diwujudkan manjadi tindakan nyata, yaitu (a) Mengajarkan kepada siswa kompetensi untuk memecahkan berbagai persoalan yang dialami siswa secara adil. (b) Mengajarkan kepada siswa keinginan untuk melaksanakan sesuatu yang baik dan keinginan untuk menolak godaan, menentang dan melawan godaan untuk melakukan hal yang buruk. (c) Mengajarkan kepada siswa kebiasaan yang dilakukan secara berulang-ulang, sehingga seringkali seseorang melakukan hal yang baik karena faktor kebiasaan agar dapat membantu siswa dalam berbagai situasi. Tindakan moral yang dapat mendorong setiap manusia untuk terus melakukan perilaku moral dan menghirdari perilaku yang buruk.

4. Moral sinverbal/ sinverbal karakter/ perkataan dan simbolitas moral/ perkataan dan simbol positif

Pada wilayah moral sinverbal guru mengajarkan kepada siswa dalam pembelajaran ilmu pengetahuan sosial bagaimana membuat pengetahuan moral dan perasaan moral dapat diwujudkan manjadi suatu perkaatan atau penggunaan simbol, yang mancakup (a) Mengajarkan kepada siswa seleksi setiap kata yang akan diucapkan dan menyeleksi setiap simbol-simbol yang akan digunakan siswa dalam melakukan interaksi dengan orang atau siswa lain (b) Mengajarkan kepada siswa penggunaan kata dan 
simbol-simbol moral yang merupakan hasil seleksi untuk berinteraksi dengan orang lain. (c) Mengajarkan kepada siswa revisi atau melakukan perbaikan kata yang diucakan ataupun simbol-simbol yang digunakan untuk selalu menggunakan kata dan simbolsimbol moral.

\section{Moral habitus/ habit karakter/} kebiasaan moral/ kebiasaan positif

Pada wilayah moral habitus/ habit guru mengajarkan kepada siswa dalam pembelajaran ilmu pengetahuan sosial bagaimana tindakan moral dapat terus dipertahankan menjadi suatu habitus, yang mencakup (a) Mengajarkan kepada siswa desiminasi atau menyebarluas pengetahuan, perasaan, perkataan dan penggunaan simbol moral kepada orang lain. (b) Mengajarkan kepada siswa peneriman habitus untuk menerima pengetahuan, perasaan, perkataan dan penggunaan simbol moral yang diperoleh dari hasil interaksi dengan orang lain. (c) Mengajarkan kepada siswa habitus kolektif utuk selalu melakukan sesuatu sesuai dengan kebiasaan kelompok.

6. Moral culture/ culture karakter/ budaya moral/ kebudayaan positif
Pada wilayah moral culture guru mengajarkan kepada siswa dalam pembelajaran ilmu pengetahuan sosial bagaimana mambuat pengetahuan moral, perasaan moral, perkataan dan penggunaan simbol moral, tindakan moral, habitus moral dapat terus dijadikan sebagai suatu kebudayaan suatu kelompok masyarakat. Sistem moral yang terbentuk mencakup seluruh aspek kehidupan kelompok masyarakat seperti agama, pendidikan, politik, ekonomi dan lainlain, hal-hal yang diajarkan antara lain: (a) Mengajarkan kepada siswa sistem moral cultural (culture moral system) suatu norma atau aturan yang menjadi pegangan kelompok masyarakat dan memiliki sangsi sosial bagi yang melanggar. (c) Mengajarkan kepada siswa peradaban (civilization) yaitu identitas kelompok melalui proses kritalisasi nilai moral yang menjadi tolak ukur perilaku manusia.

\section{Simpulan}

Model integrasi pendidikan karakter terhadap pembelajaran ilmu pengetahuan sosial di sekolah dasar dapat dilakukan melalui moral knowing, moral feeling dan moral action, moral sinverbal, moral habitus, 
dan moral culture sebagai model integrasi pendidikan karakter bangsa dalam diri setiap siswa mulai level individu sampai pada kelompok masyarakat, yang dapat dapat diintegrasikan dengan nilai-nilai karakter bangsa dalam proses pembelajaran.

\section{Daftar Pustaka}

Ahmad, T. A. (2014). Kendala Guru dalam Internalisasi Nilai Karakter pada Pembelajaran Sejarah. Khazanah

Pendidikan, $7(1)$.

Ahya, H. (2013). Pendidikan Karakter di SMA Santo Bonaventura Madiun (Doctoral dissertation, University of Muhammadiyah Malang).

Akhwan, M. (2014). Pendidikan Karakter: Konsep dan Implementasinya dalam Pembelajaran di Sekolah/ Madrasah. El Tarbawi, 8(1), 6167.

Amini, Y. S. J. (2008). Bullying: mengatasi kekerasan di sekolah dan lingkungan sekitar anak. Grasindo.

Arifin, I. (2017). Kompetensi Kepribadian Kepala Sekolah
Berbasis Moral Spiritual dalam Mengimplementasi Pendidikan Karakter.

Ariyani, Neni \& Wismiarti. (2004). Panduan Pendidikan Sentra untuk PAUD. Jakarta: CCCRT.

Azmi, N. (2017). Manajemen Pendidikan Karakter Siswa Man 1 Brebes dan MAN 2 Brebes. Purwekerto: Institut Agma Islam Negeri Purwerkerto.

Badan Penelitian dan Pengembangan, Kemenpan. (2011). Panduan Pelaksanaan Pendidikan Karakter. Jakarta: Pusat Kurikulum dan perbukuan. Boojest. (2013). Karakteristik Siswa Sekolah Dasar (online) https://jejecmsbhnajar.wordpre ss.com/2013/04/23/karakteristi k-dan-perkembangan-belajarsiswa-di-sekolah-dasar/. Diakses tanggal 27 bulan Mei Tahun 2018.

Cahyono, H., Suhono, S., \& Khumairo, A. (2018). Pendidikan Karakter Bagi Pelaku Pedofilia (sebuah Strategi dalam Mengatasi Amoral). JMKSP (Jurnal Manajemen, Kepemimpinan, dan Supervisi Pendidikan), 3(1). 
Depdiknas. (2003). Undang-Undang

Nomor 20 Tahun 2003, Tentang

Sistem Pendidikan Nasional.

Jakarta: Depdiknas.

Depdiknas. (2006). Permen Nomor 22

Tahun 2006. Jakarta: Depdiknas.

Echols, John M dan Hassan Shadily. (2014). Kamus Inggris-Indonesia. Jakarta: PT. Gramedia.

Emzir. (2010). Metodologi Penelitian Kualitatif Analisis Data. Jakarta: Raja Grafindo Perkasa.

Goleman, D. (2000). Working With Emotional Intelligence (Terjemahan Alex Kantjono W)". Jakarta: PT Gramedia Pustaka Utama.

Gunawan, H. (2012). Pendidikan Karakter (Konsep Dan Implementasi). Bandung: Alfabeta.

Herawan, K. D., \& Sudarsana, I. K. (2017). Relevansi Nilai Pendidikan Karakter Dalam Geguritan Suddhamala Untuk Meningkatkan Mutu Pendidikan Di Indonesia. Jurnal Penjaminan Mutu, 3(2), 223-236.

Kesuma, D., Dkk. (2011). Pendidikan Karakter, Kajian Teori dan Praktik di Sekolah. Bandung: PT Remaja Rosdakarya Offset.
Lickona, T. (2012) Education for Character: Mendidik untuk Membentuk Karakter. Jakarta: PT Aksara.

Losa, J., Tasik, F., \& Purwanto, A. (2018). Peranan Orang Tua dalam Mengatasi Kenakalan Remaja Akibat Meminum Alkhohol Cap Tikus (Studi Kasus di Desa Talawaan Kecamatan Talawaan Kabupaten Minahasa Utara)".JURNAL Administrasi Publik, 1(043).

Marlina, L., \& Nurman, G. (2017). Pengembangan Pendidikan Karakter Dan Kebangsaan Di SMK Pab 1 Helvetia.

Megawangi, R. (2006). Pendidikan Yang Patut Dan Menyenangkan. Jakarta: Viscom Pratama.

Moleong, L.J. (2013). Metode Penelitian Kualitatif. Edisi Revisi. Bandung : PT. Remaja Rodaskarya.

Novitasari, K. (2017). Pembelajaran Berbasis Proyek untuk Menanamkan Karakter Tanggung Jawab pada Anak Kelompok B Di Tk Nasima Kota Semarang. $P G$ PAUD Universitas PGRI Yogyakarta.

Pulungan, F. R. (2012). Pengaruh Model Pembelajaran Problem 
Based Learning Berbasis

Pendidikan Karakter terhadap

Perubahan Karakter dan

Kemampuan Menyelesaikan

Masalah Fisika. Jurnal Penelitian

Inovasi Pembelajaran Fisika, 4, 38-43.

Qibtiyah, M. (2017). Manajemen pendidikan Madrasah Aliyah Binaan Pesantren dalam Pengembangan karakter Peserta Didik. Jurnal Bimbingan dan Konseling Ar-Rahman, 2(1).

Rohayati, N. (2018). Peranan Muhammadiyah Dalam Membina Generasi Muda Melalui Pendidikan Karakter Di Sukajadi Kota Bandung. Empowerment, 2(2), 116-125.

Rohendi, E. (2018). Mengembangkan Sikap dan Perilaku Anak Usia Dini melalui Pendidikan Berbasis Karakter. Cakrawala Dini, 3(1).

Sebrinariz. (2014). Karakteristik dan

Ciri Khas Anak SD Serta Implikasi Terhadap Pendidik (Online) http://sabrinariz.blogspot.co.id/ 2014/05/karakteristik-dan-cirikhas-anak-sd.html. Diakses tanggal 27 bulan Mei Tahun 2018.
Simatupang, L. Y. (2018). Perilaku Menyimpang Para Remaja Penghisap Lem di Kelurahan Pasar Merah Barat Kecamatan Medan Kota Sumatera Utara.

Sudarsana, I. K. (2018). Membina Kerukunan Antar Siswa Di Sekolah Melalui Penanaman Pendidikan Budi Pekerti Berbasis Kearifan Lokal. In Prosiding Seminar Nasional Kearifan Lokal Indonesia Untuk Pembangunan Karakter Universal 2015 (pp. 242-250).

Sugiyono. (2014). Metode Penelitian Kuantitatif Kualitatif dan R\&D. Bandung: Alfabeta.

Triestuning, E., Wachid, W., \& Sari, L. N. (2016). Gambaran Sikap Remaja Dalam Mengkonsumsi Minuman Keras Di Desa Sidowayah RW. 05 Sidoarjo. Nurse and Health, 5(2), 4-6.

Usman, H., \& Raharjo, N. E. (2012). Model Pendidikan Karakter Kewirausahaan di Sekolah Menengah Kejuruan. Jurnal Pendidikan Teknologi dan Kejuruan, 21(2). 